\title{
102 超音波断層法によるミズダコの口球運動の可視化
}

\author{
東大・教養・宇宙地球科学 清野聡子
Ultrasonographic Visualization of Buccal Mass Movements in North Pacific Giant Octopus Paroctopus dofleini

\section{Satoko SEINO *}

Buccal mass is a distinctively spherical organ for feeding, and specific to cephalopods. Its movement in feeding has not been observed in vivo. It was successful that ultrasonography (Aloka SSD-500) could visualize buccal mass movement in Paroctopus dofleini. $5.0 \mathrm{MHz}$, linear scannig was the best frequency to visualize the body of this species. The buccal mass rotated 8.6 times per minute, angles of rotation were in the range between 50 and 65 degrees in sagittal section.

〈目的〉 頭足類（イカ・タコ類）に特徽的な”口球”は、嘴（カラストンビ）を包 む「球状」の筋肉塊である。動物体に球状の器官は珍しく、その運動メカニズムは興味 を持たれてきた。この口球 buccal mass は、摄餌器官として本分類群の行動・生態に扔 いて重要な役割を果たしている。

形態的には、器官全体は、放射状に広がる脚の基部に位置する衰状の空隙にはまって おり、食道によって懸垂されている。口球の形状自体が特殊な運動様式を示唆している と言え、これは囊内で回転していると予想されてきた。遊泳性のイカ類やオウムガイ類 では、掑慨時に竹の間から跴の先端と口球唇の部分が観察出来る。しかし、口球は体内 器官であるうえ、脚と腕間膜の存在が観察を阻んでいるので、全体の動く様子は実際に 観察されたことはない。

行動的側面では、嘴か歯舌で腹足類や二枚貝の款を穿孔することが知られているが、 どのように口で穿孔を行なうのか詳細はわかっていない。

鳥類や爬虫類の嘴からの類推から、頭足類の口球中の嘴も「噛みついて、ちぎる」機 能形態を持つと想定されてきた。また、嘴の間にある歯舌は、その鍣歯を平面に站べた ような形態から、それで慨をかき取るように食しているとされてきた。しかし、頭足類 の嘴は頭蓋に直結して抢らず、筋肉構造から推して、他分類群の生物器官のアナロジー では解浃できないメカニクスが予想された。

そこで、発表者は水中生物の体内部を透視し観察できる超音波断層法を用いて、口球 の運動の可視化を試みた。

\footnotetext{
* Department of Earth Science and Astronomy, College of Arts and Sciences, University of Tokyo,

3-8-1, Komaba, Meguro-ku, Tokyo
} 
く材料と方法〉 実験は、北海道大学水産学部臼尻水産実験所にて行なった。噴火 湾に面する南茅部町臼尻の地先で採集されたミズダコ Paroctopus dofleini（体重9.8kg） を水槽に収容し、計測対象とした。超音波断層装置Aloka SSD-500、共振周波数は ${ }^{2} 3.5 \mathrm{MHz},, 5.0 \mathrm{MHz} 、 7.5 \mathrm{MHz}$ 、またスキャニング方式はリニア、コンベックスの各種の 超音波プローブを用い、現行の器材のうち、可視化に最適の周波数と方式を確定した。 ホタテガイの軟体部を給慨し、摂䭒前と途中の観察を行った。無侵襲計測を目指して、 動物を押さえ付けることなく、超音波プローブを水面に懸垂、および動物に軽く接触さ せて、頭部の横断面、縦断面の断層像のビデオ記録を取得した。

〈結果〉 超音波断層法により、ミズダコのロ球の運動が可視化された。縦断面画像 によると、球 7 秒に 1 回の割合で、50〜65度回転運動する様子が描出された。横 断面像によると、背一腹方向に上下運動していた。回転運動は口球を収めている裹状の 空間内で起き、摂飭行動は、頭部全体を動かさずに出来ることがわかった。

嚥下は、口球が回転する直後に起き、塊となった飭が口から肝臓の背側の消化管を通っ て移動し、外套の奥にある胃に収まる様子も観察できた。組織である顎板は強い反射を 示したので容易に識別でき、咬むためのスライドするような開閉が視られた。顎板によっ て遮蔽されシャドーが出来るため、蒾舌自体の運動は明確には磪認出来なかった。

本種のこの行動の観察には、特に、リニアスキャンの共振周波数 $5 \mathrm{MHz}$ のプローブを用 いれば鮮明な画像が得られることが分かった。

〈考察〉 本実験の、超音波断層法による生体の夕コ類の可視化によって、口球の運 動は裹内での回転運動が初めて証明された。「球状の器官」のバイオメカニクス的意味 を積極的に評価する材料が得られたことになる。

観察された間久的かつ規則的な回転運動は、嘴が咀夁というよりも、择き取りに使わ れていることを示している。噛みついた後に、口球全体が回転することにより、描き取っ ているのである。そのため、咀嚼作用は歯舌が専門的に行なっていると言える。

ミズダコのような底棲八腕類では、上記のような口球だけを動かし、体全体を動かさ なくてもよい運動は、”着棲”に適していると考えられる。䬣を吸盤で保持し、腕と腕 間膜を利用して覆ってしまえば、あとは少しずつちぎって食すればいいことになる。一 方、鳥類などの口は体外に露出していて、頭蓋に直結しているために、慨に噛みついて ちぎる場合には、頭全体を動かさねばならず、さらに咀嚼の振動が直接頭に伝わる。

頭足類の”口球”という内蔵型揕餌器官のメカニクスの利点は、萧内での回転運動で、 さらに他の器官と直結していないことにある。運動により発生する外部への力は、口球 付近で吸収されてしまい、この部位がひとつのシステムとして完結する。

イカ類など遊泳生活を送る他の頭足類は、遊泳・呼吸を継続しつつ摄䭒も行なう。上 記のこの口球のメカニクスは、ネクトン（遊泳生物）についても利点が考えられる。す なわち、掑飭に伴う運動は頭部でほぼ完結し、ジェット推進で律されている運動系に影 響をほとんど与えない可能性が示唆された。 